\title{
Diseases of salmonids resembling myxosporean whirling disease, and the absence of Myxosoma cerebralis, in South America
}

\author{
M. L. Margolis ${ }^{1}$, M. L. Kent ${ }^{1}$, P. Bustos ${ }^{2}$ \\ ${ }^{1}$ Department of Fisheries and Oceans, Pacific Biological Station, Nanaimo, British Columbia, Canada V9R 5K6 \\ ${ }^{2}$ Servicio de Ictiopatología, Areas de Acuicultura y Medio Ambiente, Departamento de Recursos Marinos, Fundación, \\ Castro, Chile
}

\begin{abstract}
Previously published reports of whirling disease (WD) of salmonids (rainbow trout Oncorhynchus mykiss, chinook salmon $O$. tshawytscha and coho salmon $O$. kisutch) in 4 South American countries (Venezuela, Colombia, Ecuador, Chile) are reviewed. The disease(s) were shown not to be associated with infections with the myxosporean Myxobolus cerebralis, the cause of myxosporean WD. Our recent observations in Ecuador and Chile of salmonid diseases with clinical signs resembling those of myxosporean WD further demonstrated that the diseases in South America were not caused by $M$. cerebralis. In Chile, the diseases in coho salmon and rainbow trout were attributed to bacterial infections, whereas no infectious agent was associated with afflicted rainbow trout in Ecuador We conclude that myxosporean WD of salmonids does not occur in South America. The causes of several other diseases of salmonids with clinical signs similar to those of myxosporean WD (e.g. whirling behaviour. skeletal deformities, blackened tails) include bacterial or microsporidial infections of the meninges or brain, myxobacterial infections of the vertebrae, and dietary deficiencies. A diagnosis of myxosporean WD, therefore, cannot be made on clinical signs alone. Laboratory confirmation of the diagnosis through demonstration of the presence of $M$. cerebralis is necessary
\end{abstract}

KEY WORDS: Whirling disease - Myxobolus cerebralis ' Salmonids - Skeletal deformities - Spiral swimming Flexibacter psychrophilus . Renibacterium salmoninarum · South America

\section{INTRODUCTION}

Whirling disease (WD) is an ailment of rainbow trout Oncorhynchus mykiss first described in Germany by Hofer (1903). The disease is caused by the myxosporean Myxobolus cerebralis Hofer, 1903, which infects cranial and other cartilaginous skeletal elements. It is now known from most countries in continental Europe and from the former USSR, and has been introduced to the United States, New Zealand, South Africa, and the British Isles (Hoffman 1970, 1990, Markiw 1992). Herein we refer to this disease as myxosporean WD. Signs of the disease include whirling in a horizontal plane (known as 'tail-chasing'), deformities of the head, spinal curvature, shortened opercula, and blackening of the caudal region (Hoffman et al. 1969, Cordero del Campillo et al. 1975, Halliday 1976 , Schäperclaus 1986, Markiw 1992).
In South America, diseases with clinical signs resembling those of typical myxosporean WD have been reported since the early 1970 s in several populations of rainbow trout and other salmonids. Although these diseases have been identified as 'whirling disease,' laboratory confirmation of the diagnosis through demonstration of the causative agent Myxobolus cerebralis has not been accomplished. Nevertheless, in some recent reviews (e.g. Schäperclaus 1986, Hoffman 1990) certain South American countries still have been included in the geographic range of myxosporean WD. It is important to clarify the status of WD in South America because of potential implications for international fish health protection measures that might be applied to trade in live salmonids and food products derived therefrom.

In the present paper we review the validity of the reported occurrences of WD in South America, and 
report on new studies in Chile and Ecuador on diseases of salmonids with clinical signs resembling those of myxasporean WD.

\section{HISTORICAL REVIEW}

The first report of WD in South America was based on a misinterpretation by Bogdanova $(1968,1970)$ of a paper published in Venezuela by Martinez (1966). Several other authors followed Bogdanova in listing Venezuela as a country from which WD has been reported (Anonymous 1969, Hoffman et al. 1969, Christensen 1973, Cordero del Campillo et al. 1975). Although Martinez (1966) discussed WD (= 'Lentosporidiasis') as a serious problem in trout rearing, he did not sidie or inply indi it occurred in Venezuela. Hoffman \& Meyers (1969) dropped Venezuela from the list of WD-affected countries stating that the authorities concerned deny the presence of WD there. Presumably on the strength of this information, Hoffman (1970) and Bogdanova (1973) deleted Venezuela from the countries in which WD has appeared, although Schäperclaus (1986) continued to include it.

According to Marín-Aponte et al. (1974), Espinoza \& Díaz-Ungría (1970) observed rainbow trout in Venezuela with signs of WD and assumed, without laboratory confirmation, that the disease was caused by Myxobolus cerebralis. Díaz-Ungría (1970) also referred to the occurrence of WD in trout, as well as in Mugil brasiliensis and Cynoscion sp., in Venezuela. Prof. Díaz-Ungría subsequently advised the first author (pers comm., July 13, 1976) that $M$. cerebralis was not isolated from these fish and that it was necessary to conclude that myxosporean WD has not been demonstrated to exist in Venezuela.

Martinez (pers. comm. to the first author, April 20 , 1970), Marín-Aponte et al. (1974), Marín (1974-75), Halliday (1976), Ghittino \& Vigliani (1978), and Conroy (1981) all have stated that WD is absent from Venezuela. Marin-Aponte et al. (1974) investigated a rainbow trout disease in Venezuela having signs resembling myxosporean WD, but histological examination revealed that Myxobolus cerebralis was not the causative agent. Possibly, the disease they studied and that observed by Espinoza \& Díaz-Ungría (1970) and Díaz-Ungria (1970) were the same as that reported later from Colombia by Conroy (1975).

Conroy's (1975) interest and study of the disease in Colombia followed from an anonymously authored item in the FAO Fish Culture Bulletin (Anonymous 1972) reporting that WD occurred in rainbow trout from 4 Colombian trout rearing facilities. Conroy (1975) undertook detailed studies of afflicted rainbow trout in several hatcheries and fish farms in Colombia, including 2 that were mentioned in Anonymous (1972). The failure to detect Myxobolus cerebralis in any of these fish led Conroy $(1975,1981)$ to conclude that myxosporean WD does not exist in Colombia. One of the signs of the disease investigated by Conroy (1975) was whirling around the longitudinal axis of the fish, in contrast to the horizontally circular whirling in the form of tail-chasing that is characteristic of WD caused by $M$. cerebralis. Apparently, the report of WD in Anonymous (1972) involved an incorrect diagnosis based solely on clinical signs without laboratory confirmation.

At about the same time that the reports from Venezuela and Colombia appeared in the literature, a brief note in the FAO Aquaculture Bulletin, attributed to Vieschikat $(1971)$, reported the occurrence of WD in 2 trout hatcheries in Ecuador. All infected fish had been raised from eggs imported from Colombia. The note stated that the 2 hatcheries were infected with Myxobolus cerebralis. However, Dr Meschkat (pers. comm. to the first author, October 3, 1975) advised that his diagnosis was based on external signs only and that affected fry were not examined microscopically. Conroy (1981) reported a similar response to his enquiries about the disease in Ecuador. It seems likely that the disease reported from Ecuador is the same as that investigated by Conroy (1975) in Colombia and is not myxosporean WD.

The inclusion of Colombia and/or Ecuador by Cordero del Campillo et al. (1975), Christensen (1973), and Halliday (1976) among the countries that have experienced myxosporean WD apparently stems from the original FAO reports. Despite Conroy's $(1975,1981)$ results and views about the nature of the disease reported from Colombia and Ecuador, Hoffman (1990) continued to list these countries among those with a history of myxosporean WD.

Apparently, the least known report (Anonymous 1974) of WD in a South American country is that for Chile. This anonymously authored report, prepared by the División de Pesca y Caza, Servicio Agrícola y Ganadero, Ministeria de Agricultura, on aquaculture in Chile, noted that 'mixosomiasis' (= WD) has been diagnosed there in Pacific salmon. No further details were provided. According to a former Director of the Division Protección Pesquera, Chile (pers. comm. to the first author, October 15, 1976), the affected species were Oncorhynchus kisutch (coho salmon) and $O$. tshawytscha (chinook salmon), and the diagnosis was based on clinical signs without laboratory confirmation of the presence of Myxobolus cerebralis. Under these circumstances, the diagnosis must be considered suspect and requiring confirmation.

To complete the historical review, we note that Marques-Mendes (1980) reported Myxosoma (= Myxobo- 
lus) cerebralis as the cause of scoliosis in Mugil brasiliensis from the southern coast of Brazil. No evidence was presented to support this diagnosis.

\section{RECENT OBSERVATIONS}

\section{Ecuador}

In March 1994, one of us (M.K.) had the opportunity to examine rainbow trout with clinical signs of WD at a hatchery in the Riobamba region, Ecuador. One stock of yearling rainbow trout exhibited a variety of clinical changes suggestive of myxosporean WD, including whirling swimming, black tails, deformed vertebral columns, and flattened noses. Some fish also exhibited darkening on one half of the body exactly along the medial line. Other fish exhibited chaotic swimming behaviour with no obvious skeletal deformities. Approximately $30 \%$ of the fish (about 200) exhibited one or more of these changes.

The heads, pieces of vertebral column, and visceral organs from 5 fish with skeletal deformities were preserved in Davidson's solution and processed for histopathology. Affected skeletal areas exhibited deformation of the bone, massive periosteal proliferation, and fibroplasia. Thorough microscopic examination of bone and cartilage sections revealed no myxosporean trophozoites or spores.
Chile

As part of routine diagnostic work conducted over the last 5 yr at several private salmonid hatcheries and lake and seawater netpen farms, several cases of diseases with clinical signs of WD have been observed by one of the authors (P.B.) (Table 1). Following extensive laboratory examinations, including examinations of heads by the plankton centrifuge method (O'Grodnick 1975), Myxobolus cerebralis was not detected in any of these cases. In addition, $M$. cerebralis was not found in numerous clinically normal coho salmon and Atlantic salmon Salmo salar that were examined by the plankton centrifuge method to meet U.S. Title 50 import regulations.

\section{DISCUSSION}

Although there have been several occurrences of diseases in cultured salmonids with clinical signs resembling myxosporean WD in South America, the historical evidence and our recent observations failed to associate Myxobolus cerebralis with these diseases. Several other diseases may cause whirling behaviour or skeletal deformities in salmonid fishes. Brocklebank et al. (1995) observed spiral swimming behaviour of Atlantic salmon reared in seawater netpens associated with a microsporidium in the hindbrain. A recently

Table 1. Recent diseases of salmonid fishes in Chile with various clinical signs of whirling disease

\begin{tabular}{|c|c|c|c|c|c|c|}
\hline Species & $\begin{array}{l}\text { Developmental } \\
\text { stage }\end{array}$ & Habitat & Clinical signs & Etiology & Date & References \\
\hline $\begin{array}{l}\text { Coho salmon, } \\
\text { rainbow trout }\end{array}$ & Alevins & $\begin{array}{l}\text { Freshwater, } \\
\text { raceways }\end{array}$ & Spiral swimming, tail chasing & Unknown & $\begin{array}{l}\text { Apr-Jul } \\
1994\end{array}$ & $\begin{array}{l}\text { Authors' } \\
\text { unpubl. } \\
\text { data }\end{array}$ \\
\hline Rainbow trout & Fry, alevins & $\begin{array}{l}\text { Freshwater, } \\
\text { lake pens } \\
\text { and hatcheries }\end{array}$ & $\begin{array}{l}\text { Swimming in spiral and on } \\
\text { sides }\end{array}$ & $\begin{array}{l}\text { Flexibacter } \\
\text { psychrophilus }\end{array}$ & Oct 1994 & $\begin{array}{l}\text { Bustos et al. } \\
(1995)\end{array}$ \\
\hline Coho salmon & Juvenile & $\begin{array}{l}\text { Freshwater, } \\
\text { lake pens }\end{array}$ & $\begin{array}{l}\text { Spiral swimming on longitudi- } \\
\text { nal axis and horizontally, leth- } \\
\text { argy, exophthalmia, scoliosis, } \\
\text { retrocranial swelling, darkening } \\
\text { of body on medial line, black } \\
\text { tail, peduncle malfunctions }\end{array}$ & $\begin{array}{l}\text { Flexibacter } \\
\text { psychrophilus }\end{array}$ & $\begin{array}{l}\text { Late } 1994 \\
\text { early } 1995\end{array}$ & $\begin{array}{l}\text { Entrala et al } \\
\text { (1996) }\end{array}$ \\
\hline Rainbow trout & Juvenile & $\begin{array}{l}\text { Freshwater, } \\
\text { lake pens }\end{array}$ & $\begin{array}{l}\text { Tail-chasing, circular } \\
\text { swimming on sides }\end{array}$ & Unknown & $\begin{array}{l}\text { Late } 1994 \\
\text { early } 1995\end{array}$ & $\begin{array}{l}\text { Authors' } \\
\text { unpubl } \\
\text { data }\end{array}$ \\
\hline $\begin{array}{l}\text { Atlantic and } \\
\text { coho salmon }\end{array}$ & $\begin{array}{l}\text { Juveniles and } \\
\text { adults (from } \\
\text { post-smolt to } \\
\text { harvest size) }\end{array}$ & $\begin{array}{l}\text { Freshwater } \\
\text { and seawater } \\
\text { netpens }\end{array}$ & $\begin{array}{l}\text { Swimming on sides and } \\
\text { whirling }\end{array}$ & $\begin{array}{l}\text { Renibacterium } \\
\text { salmoninarum }\end{array}$ & $\begin{array}{l}\text { Various } \\
\text { cases, } \\
1991-1995\end{array}$ & $\begin{array}{l}\text { Bustos et al. } \\
\text { (1992) }\end{array}$ \\
\hline
\end{tabular}


described retrovirus-like virus that infects the brain causes abnormal spinning motion in various salmonid species in Japan (Oh et al. 1995). Bacterial infections of the meninges or brain by Flexibacter psychrophilus (= Cytophaga psychrophila) in coho salmon (Kent et al. 1989, Entrala et al. 1996) or rainbow trout (Bustos et al. 1995), and Renibacterium salmoninarum in Atlantic and coho salmon (Bustos et al. 1992, Speare et al. 1993), also cause spiral swimming behaviour. Furthermore, chronic infections of vertebrae by $F$ psychrophilus also cause spinal deformities that may be suggestive of myxosporean WD (Conrad \& DeCew 1967).

Ascorbic acid deficiencies may also cause skeletal anomalies in fish (Ashley et al. 1975). Black tails, lordosis, scoliosis, and flattenod heads (all typical signs of myxosporean WD) were observed in salmonids reared in Portugal, and extensive examination of these fish did not reveal Myxobolus cerebralis infections (Wolf et al. 1981). No infectious agents were associated with this condition and the authors attributed the disease to tryptophan or ascorbic acid deficiencies.

In Chile the recent cases of diseases resembling WD were attributed to bacterial infections (Table 1), but it is unknown if any of these were the cause of a similar disease in Chile briefly reported in 1974 (Anonymous 1974). The results of our recent observations on rainbow trout from Ecuador are similar to those previously reported from the study of afflicted trout in Colombia and Venezuela in that skeletal abnormalities were prominent and the lesions were not associated with an infectious agent.

In conclusion, as pointed out by Wolf et al. (1981), confirmation of myxosporean WD must include microscopic detection of Myxobolus cerebralis, and based on the evidence to date, $M$. cerebralis and myxosporean WD do not occur in South America. To avoid further confusion, diseases showing spiral or whirling behaviour or skeletal deformities in the absence of $M$. cerebralis should not be called 'whirling disease' or the Spanish equivalent 'enfermedad de torneo'.

\section{LITERATURE CITED}

Anonymous (1969) Whirling disease. FAO Fish Cult Bull 1. (2): 10

Anonymous (1972) Whirling disease in Colombia. FAO Aquacult Bull 4(3):11-12

Anonymous (1974) Situación actual de la acuicultura continental en Chile. Simposio FAO/CARPAS Sobre Acuicultura en America Latina, Montevideo, Uruguay, 26 de noviembre al 2 de diciembre de 1974. CARPAS/6/74/SC8, Oct 1974. FAO, Rome

Ashley LM, Halver JE, Smith RR (1975) Ascorbic acid deficiency in rainbow trout and coho salmon and effects on wound healing. In: Ribelin WE, Migaki G (eds) The path- ology of fishes. The University of Wisconsin Press, Madison, $\mathrm{p} 769-789$

Bogdanova EA (1968) Modern data on the distribution and biology of Myxosoma cereuralis (Protozoa, Cnidosporidia) as agent of whirling disease of salmonids. Bull Off Int Epiz 69:1499-1506

Bogdanova EA (1970) On the natural nidus of whirling disease of salmonids and the methods of its formation. Vopr Prirod Ochagovost Bolez 3:147-154 (in Russian)

Bogdanova EA (1973) A summary of worldwide investigations on whirling disease of salmonids. In: Dill WA (ed) Symposium on the major communicable fish diseases in Europe and their control. Panel reviews and relevant papers EIFAC Tech Pap 17 (Suppl 2):231-239

Brocklebank JR, Speare DJ, Kent ML (1995) Microsporidian encephalitis of farmed Atlantic salmon (Salmo salar). Can Vet J 36:631-633

Bustos P, Calbuyahue J, Montaña J, Opazo B, Entrala P, Solervicens R (1995) First isolation of Flexibacter psychro philus, as causative agent of rainbow trout fry syndrome (RTFS), producing rainbow trout mortality in Chile. Bull Eur Ass Fish Pathol 15:162-164

Bustos P, Poblete A, Navarro J, Montaña J (1992) Reportes de meningo-encefalitis asociado a transtornos conductuales por BKD (bacterial kidney disease) en salmon coho 10 . kisutch) en la X y XII region, Chile. XIII Panamerican Congress of Veterinary Medicine, Santiago, p 366

Christensen NO (1973) Whirling disease (Myxosomiasis) in salmonids. In: Dill WA (ed) Symposium on the major communicable fish diseases in Europe and their control. Panel reviews and relevant papers. EIFAC Tech Pap 17 (Suppl 2):218-223 (French version, p 224-230); references, p $237-239$

Conrad JF, DeCew M (1967) Observations on deformed juvenile coho salmon. Fish Comm Oregon Res Briefs 13:129

Conroy DA (1975) Informe sobre las enfermedades de la trucha arco iris (Salmo gairdnerii) en Colombia. Proyecto para el desarrollo de la pesca continental, INDERENAFAO, Publ no. 1, Bogota, p 1-37

Conroy DA (1981) The importance of fish diseases in relation to the development of salmonid culture in South America. Rev Ital Piscicolt Ittiopatol 16:57-64

Cordero del Campillo M, Escudero-Díez A, Alvarez-Pellitero MP, Rojo-Vázquez FA (1975) Torneo de la trucha (myxosomosis). Revision. Suppl Cient Bol Inform Cons Gen Coleg Vet España 201:5-28

Díaz-Ungría C (1970) Parasitología de los animales domésticos en Venezuela, Vol I. Universidad del Zulia Consejo de Desarrollo Científico y Humanístico, Maracaibo, p 779-783

Entrala P, Bustos P، Montaña J, Opazo B, Calbuyahue J (1996) First isolation of Cytophaga psychrophila (F. psychrophilus) as a causative agent of nervous disorder in fingerling coho salmon (Oncorhynchus kisutch) in Chile. Bull Eur Ass Fish Pathol (in press)

Espinoza V, Díaz-Ungría C (1970) Presencia de la enfermedad del 'torneo' en peces de Venezuela. Proyecto MAC-FAO, Facultad de Ciencias Veterinarias de la Universidad del Zulıa, Maracaibo

Ghittino P, Vigliani E (1978) La mixosomiasi della trota: una vecchia parassitosi d'importanza attuale. Riv Ital Piscicolt Ittiopatol 13:15-20,49-58

Halliday MM (1976) The biology of Myxosoma cerebralis: the causative organism of whirling disease of salmonids. J Fish Biol 9(4):339-357

Hoter B (1903) Ueber die Drehkrankheit der Regenbogenforelle. Allg FischZtg 28:7-8 
Hoffman GL (1970) Intercontinental and transcontinental dissemination and transfaunation of fish parasites with emphasis on whirling disease (Myxosoma cerebralis). In Snieszko SF (ed) A symposium on diseases of fishes and shellfishes. Am Fish Soc Spec Publ 5:69-81

Hoffman GL (1990) Myxobolus cerebralis, a worldwide cause of salmonid whirling disease. J Aquat Anim Health 2:30-37

Hoffman GL, Dunbar CE, Bradford A (1969) Whirling disease of trouts caused by Myxosoma cerebralis in the United States. US Fish \& Wildl Service, Spec Sci Rep, Fisheries No. 427 (with addendum), Washington, DC

Hoffman GL, Meyers U (1969) Occurrence of whirling disease. FAO Fish Cult Bull 2(1):13

Kent ML, Groff JM, Morrison JK, Yasutake WT, Holt RA (1989) Spiral swimming behaviour due to cranial and vertebral lesions associated with Cytophaga psychrophila infections in salmonid fishes. Dis Aquat Org 6:11-16

Marín C (1974-75) Whirling disease absent in Venezuela. FAO Aquacult Bull $7(1-2): 21-22$

Marín-Aponte C, de Urbina FR, Lozano O, de Peraza LA (1974) Investigaciones sobre un sindrome parecido a la 'enfermedad del torneo' en truchas arco iris Salmo gairdnerii de Venezuela. Simposio FAO/CARPAS Sobre Acuicultura en America Latina. Montevideo, Uruguay, 26 de noviembre al 2 de diciembre de 1974. CARPAS/6/74/SE

Responsible Subject Editor: W. Körting, Hannover, Germany
11, Oct 1974. FAO, Rome

Markiw ME (1992) Salmonid whirling disease. US Dept Int, Fish Wildl Serv, Fish Wildl Leafl 17

Marques-Mendes A (1980) Patologia de peixes. Cienc Cult 32:1532-1533

Martinez CR (1966) Contribución al estudıo de las enfermedades de las truchas en Venezuela. Bull Off Int Epiz 65: $1135-1162$

Meschkat A (1971) Whirling disease in Ecuador. FAO Aquacult Bull 3(2):11

O'Grodnick JJ (1975) Whirling disease Myxosoma cerebralis spore concentration using the continuous plankton centrifuge. J Wildl Dis 11:54-57

Oh MJ, Yoshimizu M, Kimura T, Ezura Y (1995) A new virus isolated from salmonid fish. Fish Pathol 30:23-32

Schäperclaus W (1986) Fish diseases, Vol 2. Akademie-Verlag, Berlin, p 597-1398 (English translation, 1991, US Dept Commerce, National Technical Information Service, Springfield, VA)

Speare DJ, Ostland VE, Ferguson HW (1993) Pathology associated with meningoencephalitis during bacterial kidney disease of salmonids. Res Vet Sci 54:25-31

Wolf K, Markiw ME, Machado Cruz J, Galhano MH, Eiras J, Herman RL (1981) Non-myxosporidan blacktail of salmonids. J Fish Dis 4:355-357

Manuscript first received. July 7, 1995

Revised version accepted: October 24, 1995 
values were not only lower than by neutralization, but also under 20 in 2 cases (serological relatedness of SBR with GSV and CRV). This disparity between results from the 2 techniques could be due to involvement of different epitopes in the antibody-antigen reaction.

In a previous study Dopazo et al. (1992) found some relationship between neutralization ratios and RNA profiles of several aquareovirus strains, and established that cross-neutralization is the best tool for studying serological relatedness among aquareoviruses. The results presented here agree with that conclusion. On the other hand, since the $1 / t$ values are usually lower by immunodot than by neutralization tests, as shown in the present study and in previous reports (Dopazo et al. 1992), perhaps the criterion for determining serogroups by neutralization $(1 / r>20)$ should be changed for immunodot data. Finally, it appears that the serogroups determined by cross-neutralization correlate with the genogroups established by Lupiani et al. (1993); however, further studies including a larger number of aquareovirus strains must be conducted to confirm that conclusion.

Acknowledgements. This work was supported by Grants XUGA 20002A94 from Xunta de Galicia and MAR 89-0270 from the Comisión Interministerial de Ciencia y Tecnología (CICYT), Spain

Responsible Subject Editor: F. M. Hetrick, College Park, Maryland, USA

\section{LITERATURE CITED}

Ahne W, Kölbl O (1987) Occurrence of reovirus in European cyprinid fishes (Tinca tinca Lin.; Leuciscus cephalus Lin.). J Appl Ichthyol 3:139-141

Archetti I, Horsfall FL (1950) Persistent antigenic variation of the influenza A viruses after incomplete neutralization in vivo with heterologous immune serum. J Exp Med 92: $44.1-462$

Brady YJ, Plumb JA (1988) Serological comparison of golden shiner virus, chum salmon virus, reovirus $13 \mathrm{P} 2$ and catfish reovirus. J Fish Dis 11:441-443

Dopazo CP, Toranzo AE, Samal SK, Roberson BS, Baya A, Hetrick FM (1992) Antigenic relationships among rotaviruses isolated from fish. J Fish Dis 15:27-36

Hedrick RP, Rosemark R, Aronstein D, Winton JR, McDowell T. Amend D (1984) Characteristics of a new reovirus from channel catfish (Ictalurus punctatus). J Gen Virol 65: $152 \vec{r}-1534$

Ishiguru S, Izawa H, Kodama H, Onuma M, Mikami T (1984) Serological relationships among five strains of infectious pancreatic necrosis virus. J Fish Dis 7:127-135

Jørgensen PEV (1972) Freund's adjuvants: their influence on the specificity of viral antisera. Acta Pathol Microbiol Scand Sec B 80:931-933

Lupiani B, Hetrick FM, Samal SK (1993) Genetic analysis of aquareoviruses using RNA-RNA blot hybridization. Virology $197: 475-479$

Okamoto N, Sano T, Hedrick RP, Fryer JL (1983) Antigenic relationships of selected strains of infectious pancreatic necrosis virus and European eel virus. J Fish Dis 6:19-25

Reed LJ, Müench H (1938) A simple method of estimating fifty percent endpoints. Am J Hyg 27:493-497

Manuscript first received: January 16, 1996

Revised version accepted: May 21, 1996

\section{Erratum}

\section{Re: L. Margolis, M. L. Kent, P. Bustos}

"Diseases of salmonids resembling myxosporean whirling disease, and the absence of Myxobolus cerebralis, in South America"

\section{Dis Aquat Org 25: 33-37 (1996)}

- An error occurred in the first author's initials. The correct form is given above 